繊維製品中のカシミヤ及び他の獣毛類の MALDI-TOF 質量分析計による同定

大箸 信一 ${ }^{* 1, *} \cdot$ 出村 由香 ${ }^{* 1} \cdot$ 佐野 元昭 ${ }^{* 1} \cdot$ 吉岡陽一郎 ${ }^{* 2}$

\title{
Identification of Cashmere and Other Animal Hair Fibers in Textiles by MALDI-TOF Mass Spectrometry
}

\author{
Shinichi Ohashi ${ }^{* 1, \#,}$ Yuka Demura ${ }^{* 1}$, Motoaki Sano ${ }^{* 1}$, and Yoichiro Yoshioka ${ }^{* 2}$ \\ ${ }^{* 1}$ Genome Biotechnology Laboratory, Kanazawa Institute of Technology, \\ 3-1 Yatsukaho, Hakusan, Ishikawa 924-0838, Japan \\ ${ }^{* 2}$ Boken Quality Evaluation Institute, 1-8-15 Ue-Machi, Chuo-Ku, Osaka 540-0005, Japan
}

\begin{abstract}
We have recently developed new methods by which we can identify the animal species based on the difference in the amino acid sequences of keratin proteins using SDS-PAGE and MALDI-TOF mass spectrometry. In this paper, we report the effect of processing, especially dyeing, on the identification of animal species. The method was also successfully applied for identifying animal species in blends with natural fibers, chemical fibers, and other animal fibers. Camel, alpaca, horse, rabbit, and other animal hair fibers were used and animal species-specific peaks were observed in MALDI-TOF mass analysis.
\end{abstract}

(Received 3 October, 2013 ; Accepted 17 December, 2013)

\section{1. 緒 言}

カシミヤは獣毛の中でも最も貴重で，高価な瀻維の一 つである。一頭のカシミヤヤギから 1 年間に取れる瀻維 の量は $150 \sim 200 \mathrm{~g}$ と少量であり，世界的な供給量は極め て限られている，そのため，カシミヤ製品の品質を保証 し，消費者を守るためには鑑別技術が非常に重要である。 現在, 鑑別技術としては顕微鏡技術が実用化されている ほとんど唯一の技術で，日本では光学顕微鏡法が，欧米 では電子顕微鏡法が主に利用されている。顕微鏡法は用 いる装置も比較的安価であり，簡便な方法であるが，人 手と時間がかかり，鑑別技術者の経験に依存する部分が 大きく, また, 試料によっては顕微鏡による鑑別が極め て難しい場合があるため, 顕微鏡法に代わる, または, 補完する方法の開発が強く望まれている.

顕微鏡法の代替法としては DNA 法[1-3]が最も期待さ れており，一部実用化されているだけでなく，国際標準 化に向けた手続きが進められている[4]．DNA 法は感度 が非常に高いのが特徴であるが，濃染色されたものなど， 一部の試料については検出が困難な場合があることが報 告されている[2]。この他に，抗原一抗体反応を利用した 方法[5]などが報告されているが，いずれも実用化には

\# corresponding author

*1 金沢工業大学ゲノム生物工学研究所

*2（一財）ボーケン品質評価機構
至っていない.

獣毛の約 90\% はケラチン I , ケラチン II , ケラチン関 連タンパク質などのタンパク質からなっている. ケラチ ンタンパク質のアミノ酸配列は動物種により異なってい ることが知られており, この違いを検出することができ れば, 動物種の同定が可能である(ペプチド法). Hollemeyer らは MALDI-TOF 質量分析計を利用して羽毛及び獣毛の 同定を試み，種特異的なピークの存在を報告している [6]. しかし, その後, この方法の詳細は報告されていない.

羊毛中のケラチンタンパク質については Plowman らの 詳細な研究が報告されている $[7,8]$. これまでに, 11 種類 のタイプI ケラチンタンパク質, 6 種類のタイプII ケラチ ンタンパク質, 26 種類のケラチン関連タンパク質が報告 されている.これらのケラチンタンパク質の特徴の一つ は, シスチン含量が非常に高いことで，分子内，分子間 で多数のジスルフィド $(\mathrm{S}-\mathrm{S})$ 結合が形成されている. その ため, 一般にケラチンタンパク質は不溶性で, 分子種が 多様であることと相まって, ペプチド法を用いた獣毛の 同定を困難にしている.

著者らは, 最近, SDS-PAGE電気泳動と MALDI-TOF 質量分析計を用いた羊毛・獣毛の鑑別法を報告した [9]. 粉砕した獣毛を界面活性剤を含む緩衝液中でジチオスレ イトール (DTT)を用いて還元して可溶化し, 得られた抽 出液を SDS-PAGE 電気泳動で分離する. 得られたタンパ ク質バンドを切り出し, トリプシン処理を行った後, MALDI-TOF 質量分析計で分析することにより, $m / e=$ 
2450-2750の範囲に動物種特異的なピークを見いだした。

本報告では, 上記の方法が実際の織物などの繊維製品 に含まれている獣毛類の同定に使えるかどうかを明らか にするため, 加工, 特に, 染色の影響, 他の繊維との混 紡の影響などについて明らかにした結果を報告する。ま た, 本方法の他の動物種の同定への応用についても述べ る.

\section{2. 実 験}

\section{1 材料}

分析試料は CCMI Fiber Box 2011[10]中の繊維, および, カシミヤ・キャメルヘア工業会会員の国内紡績業より提 供を受けた繊維, 織物を用いた. 試料は更なる洗浄など は行わず，そのまま用いた。

\section{2 纎維の粉砕}

繊維はハサミで細断，または，レッチェ社製ボールミ ル（MM400）で粉砕した．粉砕した繊維は室温で真空乾燥 後, 用いた。

\section{3 繊維の還元・溶解}

$25 \mathrm{mg}$ の繊維を $1.5 \mathrm{ml}$ マイクロチューブに秤り取り, $50 \mathrm{mmol} / 1$ の DTTを含む $4 \%$ ドデシル硫酸ナトリウム (SDS), $0.1 \mathrm{M}$ リン酸緩衝液 $\left(\mathrm{pH} 7.8\right.$ )を $0.5 \mathrm{ml}$ 加え, $95^{\circ} \mathrm{C}$ に保つことで反応を開始した. 反応はアルミブロックバ スを用い, 静置状態で行った. 所定時間後, 15,000 rpmで 5 分間遠心分離し, 抽出液と不溶物を分けた. 分離した抽 出液に $100 \mathrm{mmol} / 1$ の濃度になるようにヨード酢酸アミド (IAA)を加え, $25^{\circ} \mathrm{C}$ で 30 分間反応し, $25 \mathrm{mmol} / 1$ の DTT を添加して反応を停止した. $15,000 \mathrm{rpm}$ で 5 分間遠心分離 し，以降の分析に用いた。 くり返し反応を行う場合は, 遠心分離後の不溶物に再度, DTT, SDS を含むリン酸緩 衝液を加え, 同様の操作を行った.

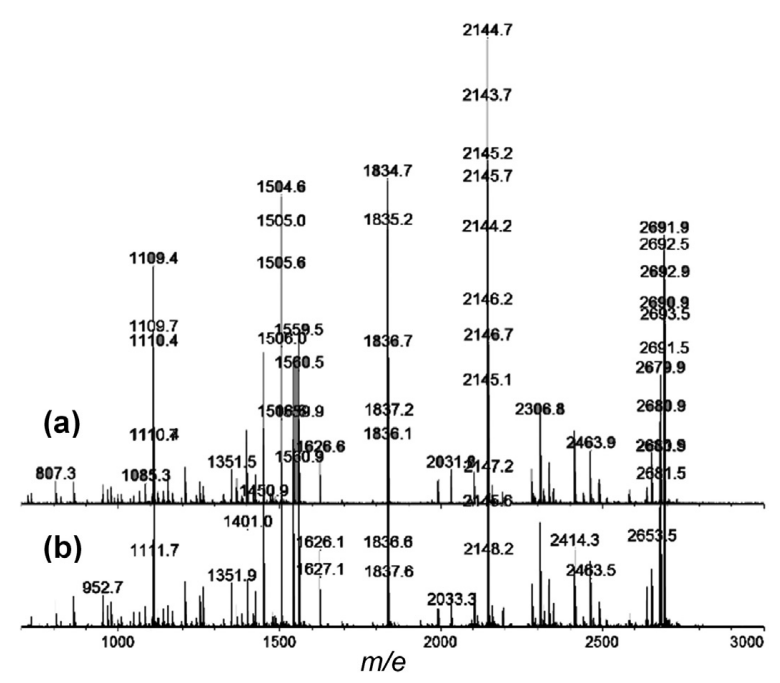

Fig. 1 Maldi-Tof mass spectra of (a) cashmere, Alashan type white and (b) cashmere, bleached from white in the region 700-3000.

\section{4 電気泳動}

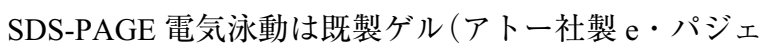
ル, ゲルサイズ $90 \mathrm{~mm} \times 83 \mathrm{~mm}$, 厚さ $1 \mathrm{~mm}$ ) および電気 泳動槽 (アトー社製 AE-6513P 型)を用いて行った. 染色 はクマシーブリリアントブルー $(\mathrm{CBB})$ (アトー社製イー ジーステイン・アクア)で行い, 水で脱色し, 写真撮影を 行った.

\section{5 スポットの採取, トリプシン処理, 質量分析}

SDS-PAGE 電気泳動ゲルからのスポットの切り出し, $\mathrm{CBB}$ の除去, ゲル内トリプシン処理, トリプシン処理ペ プチドの溶出, マトリックスとの混合, および Maldi-Tof 質量分析用金属プレートへのスポッティングはxcise (Proteome Systems, 島津製作所)を用いて行った. マトリッ クスとしては CHCA を用いた. Maldi-Tof 質量分析装置は 島津 AXIMA-CFRplusを用い, タンパク質の同定には Matrix Science 社製 Mascotを用いた. データベースとして はNCBI およびMSDBを利用した。

\section{3. 結果と考察}

\section{1 羊毛・獣毛の抽出及び同定に及ぼす加工の影響}

市販されている繊維製品のほとんどは, 漂白, 染色な どさまざまな加工が加えられている．化学分析を行う場 合, こうした加工が分析結果に影響を及ぼすことは少な くない. 一方で, 分析工程を単純化するためには前処理 をできるだけ減らし，どの試料に対しても同一の前処理 で済ませることが望ましい. そこで, 羊毛・獣毛製品の 加工処理としてょく用いられている漂白, 脱色, 染色な どの影響を調べた。

分析試料としては CCMI Fiber Box 2011 に含まれる羊毛・ 獣毛のうち, 脱色などの加工が施されたものを用いた. 羊毛・獣毛はハサミで細かく切るか, ミキサーミルで粉 砕し, 抽出は $50 \mathrm{mmol} / \mathrm{l}$ の DTTを含む $4 \% \mathrm{SDS}, 0.1 \mathrm{M}$ リ

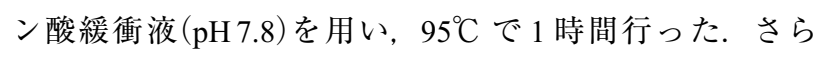
に, 遠心分離して上清を分け, 残椬に同様の抽出緩衝液 を加えて, 3 時間反応した. 抽出タンパク質溶液を SDSPAGE 電気泳動で分離し, ケラチン I が含まれるバンド を切り出し, トリプシン処理を施した後, MALDI-TOF 質 量分析計で同定を行った. Fig. 1 には, 未処理および漂白 処理を行ったカシミヤの MALDI-TOF 質量分析スペクト ルを示す. 両者のスペクトルはほとんど違いがなく, 加 工により新たなピークが生じることもなかった. 他の加 工試料についても全く同様の結果であった.

Fig. 2 には, 未処理, および加工処理を施したカシミヤ, 羊毛, ヤクの MALDI-TOF 質量分析スペクトルを示した. $m / e=2450-2750$ の領域にはカシミヤで $m / e=2692$, 羊毛 で 2665, ヤクで 2504 付近に動物種特異的ピークが現れる が, 分析を行った全ての試料についてこれらのピークが 認められた。 また, 加工により新たなピークの出現も認 められなかった. 以上のことから, 定性分析に対して白 


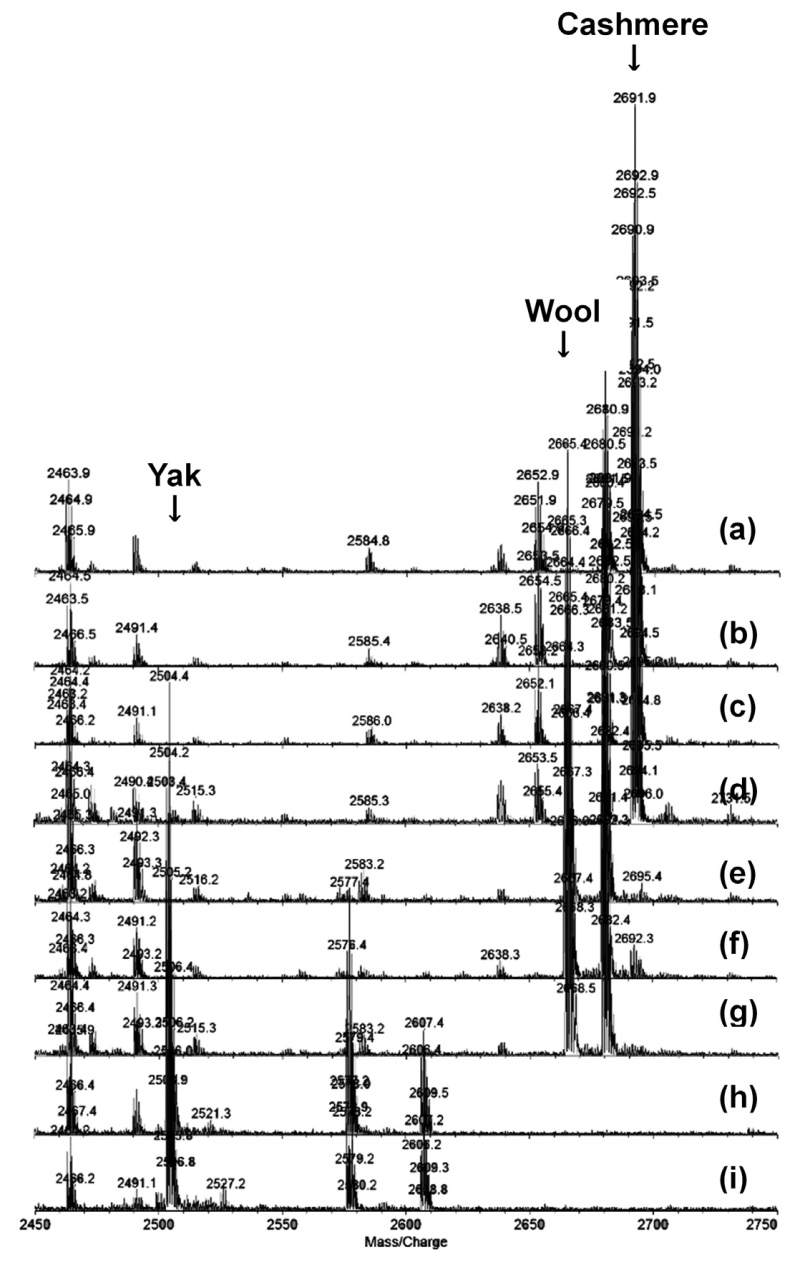

Fig. 2 Maldi-Tof mass spectra of unprocessed and processed cashmere, wool and yak in the region 2450-2750. a) Cashmere, Alashan type white; b) cashmere, bleached from white ; c) cashmere, brown; d) cashmere, decolored from brown; e) wool, fine, native sheep ; f) wool, descaled, native sheep; g) wool, steamed, native sheep ; h) yak, dark brown; i) yak, bleached.

色繊維をより白くするための漂白, 有色繊維を白くする ための脱色などの加工の影響は全くないことが明らかに なった.

つぎに，染色した試料について，同様の分析を行った. その結果を Table 1 に示す. 全ての試料について, Fig. 2 に示したのと同様の動物種特異的ピークが観察され, 染 色の影響もないことが明らかになった。

Table 1 Effect of Dyeing on Species Identification.

\begin{tabular}{cllc}
\hline Species & Product & Color & Specific Peaks \\
\hline Cashmere & Knit & Brown & $\bigcirc$ \\
Cashmere & Knit & Gray & $\bigcirc$ \\
Cashmere & Knit & Purple & $\bigcirc$ \\
Cashmere & Knit & Beige & $\bigcirc$ \\
Cashmere & Fabric & Black & $\bigcirc$ \\
Cashmere & Fabric & Black & $\bigcirc$ \\
\hline
\end{tabular}

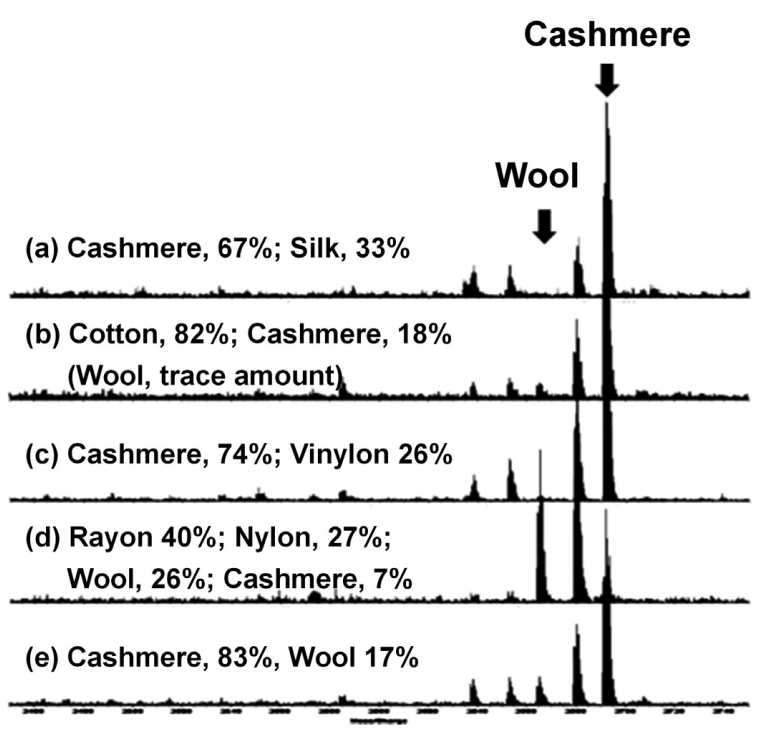

Fig. 3 Maldi-Tof mass spectra of fiber blends in the region $2450-2750$.

\section{2 綿, 絹, 化学繊維などとの混紡の影響}

市販されている獣毛製品の多くは, 綿, 絹, 麻などの 天然繊維やナイロン, レーヨンなどの化学繊維, 他の獣 毛纎維などと混紡されている.このような混紡製品であっ ても単品同様の方法で分析可能かどうかは, 方法の汎用 化にとって非常に重要である. Fig. 3 には $m / e=2450-2750$ の範囲の質量分析スペクトルを示した。本方法では羊毛. 獣毛部分のスペクトルのみが見られ, 全ての試料は単品 で見られる羊毛・獣毛特異的スペクトルを示し，また， 新たなピークも認められなかった。 絹はタンパク質であ り, 妨害ピークが現れる可能性があったが, そのような ピークも全く認められなかった.

カシミヤと羊毛の混紡品については両種の特異的な ピークが認められた.

\section{3 カシミヤ, 羊毛, ヤク以外の獣毛の分析}

これまで示して来たように，カシミヤ，羊毛，ヤクに ついては $m / e=2450-2750$ の範囲に特異的なピークが認め られ，これを用いることによって動物種を容易に同定す ることができる。そこでつぎに，この方法が他の獣毛へ 適用可能であるかを明らかにするため, 他の獣毛類につ いて同様の分析を行った. その結果を Table 2 に示す. 全 ての獣毛について $m / e=2450-2750$ の範囲に主ピークが認 められ, 多くの動物についてその位置が互いに異なった。 しかし, 近縁種, 例えば, キャメルとアルパカ, カシミ ヤとモへヤ，ウサギとアンゴラウサギなどはそれぞれ全 く同じ位置にピークが現れた。いずれの獣毛についても カシミヤ, 羊毛, ヤクの同定を妨害するピークは示さず, また, この領域を観察することで動物種の同定が可能で あることが明らかになった.

\section{4. 結 語}

羊毛・獣毛を粉砕し, 界面活性剂を含む還元剂溶液中 
Table 2 Animal Species Specific Peaks in Maldi-Tof Mass Spectrometry.

\begin{tabular}{llll}
\hline $\begin{array}{l}\text { Animal } \\
\text { Species }\end{array}$ & Type & $\begin{array}{r}\text { Peak1 } \\
(\mathrm{m} / \mathrm{e})\end{array}$ & $\begin{array}{c}\text { Peak2 } \\
(\mathrm{m} / \mathrm{e})\end{array}$ \\
\hline Yak & Bovidae & 2503 & \\
Long-tailed Chinchilla & Chinchillidae & 2556 & 2558 \\
Horse & Equidae & 2563 & \\
Marmot & Sciurida & 2581 & 2684 \\
Alpaca & Camelidae & 2583 & \\
Camel & Camelidae & 2583 & \\
Human & Hominida & 2593 & \\
Fox & Canidae & 2638 & 2711 \\
Leopard & Felida & 2651 & \\
Nutria & Myocastoridae & 2652 & \\
Lynx & Felida & 2654 & \\
Rabbit & Leporidae & 2656 & 2672 \\
Angora rabbit & Lagomorpha & 2656 & \\
Sheep & Bovidae & 2664 & \\
Swakara & Bovidae & 2664 & \\
Sable & Mustelidae & 2684 & 2698 \\
Common Raccoon & Procyonidae & 2684 & 2699 \\
Skunk & Mephitidae & 2684 & \\
Cashmere & Bovidae & 2691 & \\
Mohair & Bovidae & 2691 & \\
American Mink & Mustelidae & 2698 & 2714 \\
Raccoon dog & Canidae & 2711 & 2727 \\
\hline
\end{tabular}

で処理し, SDS-PAGE電気泳動で分離した後，質量分析 することで，原毛のみならず，纎維製品についても動物 種の同定が可能であることが明らかになった．本方法は 繊維試料の洗浄などの前処理は行わず，単にボールミル による粉砕または八サミによる細断のみでよく，また， あらゆる種類の試料について全く同じ方法を適用するこ とができる.

漂白, 脱色, 染色などの様々な加工が施された製品で あっても, 全ての試料について動物種特異的なピークが 現れ，動物種の同定が可能であった。濃い染色を施され た試料についても，同定への影響は全くなかった.

羊毛・獣毛の混紡製品の分析においてはそれぞれの動 物種特異的なピークが明膫に観察され，また，他の天然 纎維，化学繊維等が混紡されている場合にも，他の繊維
を分離せず，そのまま分析が可能であることが明らかに なった。

キャメル, アルパカ, ウサギ, ウマ, タヌキなどの獣 毛についても, 質量分析スペクトルは $m / e=2450-2750$ の 範囲にそれぞれ種特異的なピークを示し，この領域を見 るだけで, 他の動物種が混在するか否かを判断できるこ とが示された．標品があれば動物種が判別可能であり， 簡便な動物種推定法として有用であると考えられる。

\section{謝 辞}

貴重な助言をいただいた産業技術総合研究所町田雅 彦博士, 小池英明博士, カシミヤ・キャメルヘア工業会 清水邦保氏に媣く感謝いたします。

本研究は, (独) 新エネルギー・産業技術総合開発機構 (NEDO) 平成 22 年度「戦略的国際標準化推進事業」, 拈よ び，経済産業省平成 23，24 年度「戦略的国際標準化事業 (国際標準共同研究開発事業)」の支援を受けた。

\section{文 献}

1. Subramanian, T. Karthik, N. N. Vijayaraaghavan, $J$. Biotechnol., 116, 153 (2005).

2. K. Kerkhoff, G. Cescutti, L. Kruse, J. Muessig, Text. Res. J., 79, 69 (2009).

3. W. Ji, L. Bai, M. X. Yang, Forensic Sci. Int., 208, 139 (2011).

4. http : // www. meti. go. jp / information / downloadfiles / c110204d02j.pdf

5. C. Tonetti, C. Vineis, A. Aluigi, C. Tonin, Text. Res. J., 82, 766 (2012).

6. K. Hollemeyer, W. Altmeyer, and E. Heinzle, Anal. Chem., 74, 5960 (2002).

7. J. E. Plowman, J. Chromatogr. B, 787, 63 (2003).

8. S. Clerence, C. D. Cornellison, S. Deb-Choudhury, A. Thomas, J. E. Plowman, and J. M. Deyer, J. Proteomics, 73, 1722 (2010).

9. S. Ohashi, Y. Demura, M. Sano, Sen'I Gakkaishi, 68, 276 (2012).

10. http://www.cashmere.org/cm/fiber-box.php 